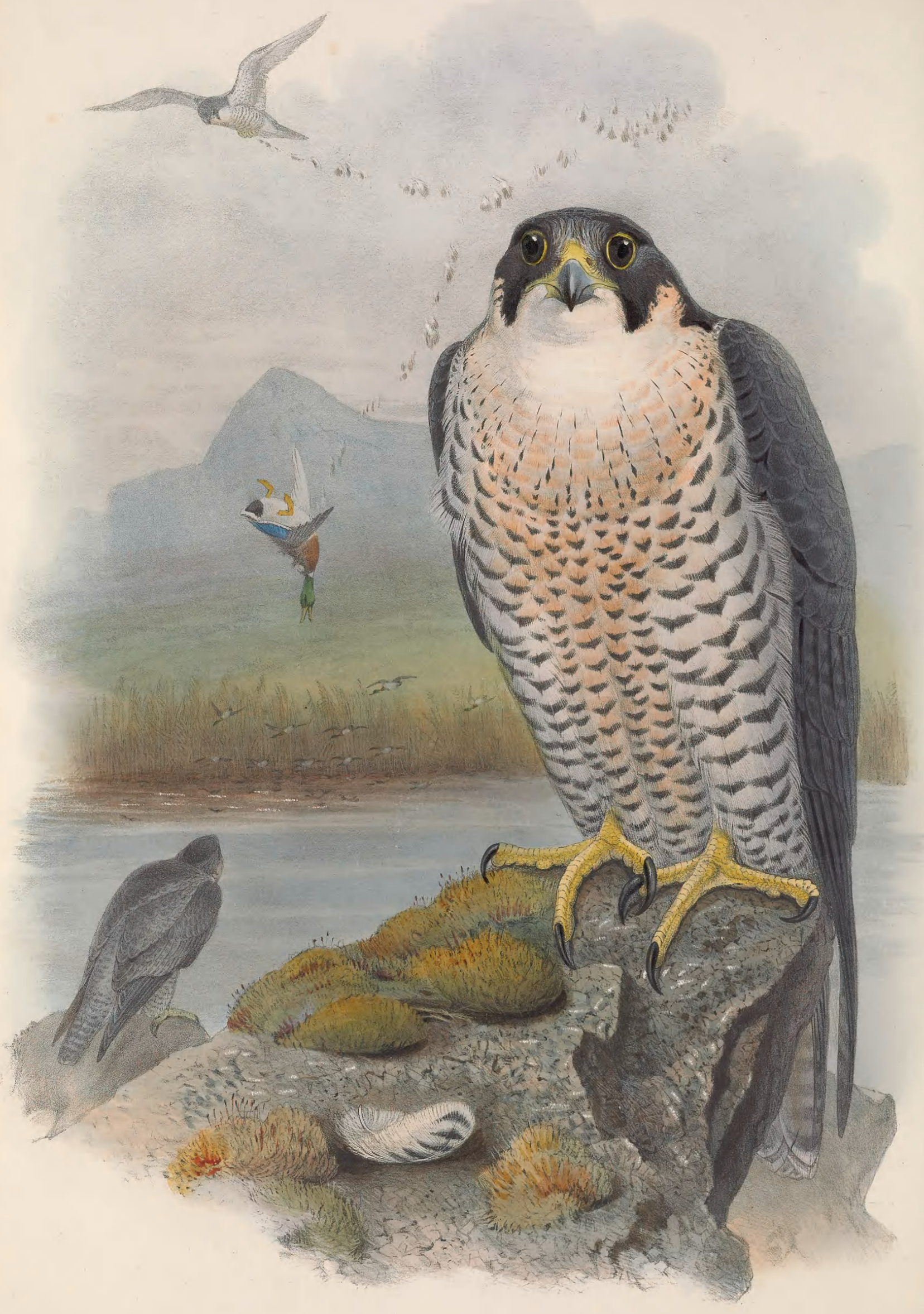

FALCD PEREGRTNUS, Gmel. 


\title{
FALCO PEREGRINUS.
}

\author{
Peregrine Falcon.
}

Falco peregrinus et communis, Gmel. et auct.; F. calidus, Lath.; F. abietinus, Bechst. ; F. micrurus, Hodgs. Bhyri of the Hindoos ; Bas of the Bucharians; and Basi of the Persians.

To enumerate the parts of Great Britain and Ireland frequented by the Peregrine would be superfluous, since it is universally, though sparingly, dispersed over the three kingdoms wherever situations occur adapted to its habits; these are generally, though not exclusively, precipitous rocks in the neighbourhood of the ocean, and bold headlands, such as Beachy Head and the cliffs of the Isle of Wight, Lulworth Cove, Wales, and Holyhead. In Scotland, the Bass Rock and all similar situations, both on the mainland and in the islands, are frequented by it; and the same may be said of the sister kingdom of Ireland, where its numbers are neither diminished nor augmented, similar conditions alone being necessary for its presence. The other countries inhabited by this bird are the continent of Europe generally, Greenland, and probably Arctic America. That it also extends its range to Northern Africa, India, Borneo, the Amoor, China, and Japan is certain, from the evidence of various writers, and from the fact of my having received specimens from nearly all those countries. Birds intimately allied to the Falco peregrimus are also found in North America, Cape Horn, at the Cape of Good Hope, in India, and in Australia, all of which, although closely resembling. each other, possess distinctive characteristics, and have rightly, I think, been regarded as so many species; they are the Falco anatum of North America, the $F$. minor of South Africa, the F.tunetanus of North Africa, the $F$. peregrinator of India, and the $F$. melanogenys of Australia. These distinctions being admitted, the Peregrines form an important section of the Falconidæ, instead of constituting a single species, as was formerly supposed ; they are all of similar habits, and they are alike destined to perform similar offices in the great scheme of nature.

The Peregrine is the Falcon "par excellence" employed in the noble sport of Falconry; but into this part of its history it will not be necessary for me to enter, so many excellent works having been written on the subject, to one of which I would, however, especially direct attention, namely, the magnificent 'Traité de Fauconnerie' of my friend Dr. Schlegel of Leyden. In days gone by, our ancestors devoted much of their time to this noble sport, preserved and cherished the Peregrine by every means in their power, and punished its destruction or molestation with great severity, many instances of which are on record.

During the period of incubation and the rearing of its progeny, when the oceanic cliffs are resorted to, it preys upon Gulls, Guillemots, Rock Pigeons, Plovers, and nearly every other bird which occurs within the area of its particular beat, and vast indeed is the destruction of life in the neighbourhood of its eyrie. In autumn the Peregrine often retires inland and takes up a position in parts likely to afford it a plentiful supply of food, particularly wooded parks and domains in the neighbourhood of large waters frequented by ducks, coots, and other water-fowl, to which it appears to be especially partial; and in such localities it would probably always remain until the next breeding-season, if left unmolested. Of this feature in the bird's economy I have some certain and curious evidence forwarded to me from Coombe Abbey, Warwickshire, by Mr. James Burdett, keeper to the Earl of Craven, who, unlike keepers in general, has, much to his credit, evinced a desire to preserve rather than to destroy this fine bird,- - line of conduct which has not only met with Lord Craven's approval, but which will be duly appreciated by every lover of nature. On the 25th of March, 1856, Burdett writes, "There has been for the last four or five years a Peregrine, and sometimes two, on the trees skirting the large water at Coombe Abbey. I have often seen them take Coots, Moor-hens, Ducks, \&c. On Sunday the 13th I saw one of them strike six Bald Coots quite dead, but it did not take any further notice of them as regards taking them for food. While Charles Lachlan Harris, Esq., and I were fishing yesterday, the 24th, the Peregrine came within five or six yards of us, and took from the water a Bald Coot by the head and carried it nearly ashore, but, on my calling out, dropped it; in two or three minutes he came again, seized another Coot by the head as before, and took it in his talons to the shore, a distance of about one hundred and fifty yards; I pushed after him, and when I had arrived within about thirty yards, he flew off, leaving the Coot behind; he had dislocated its neck, and commenced picking its breast. I send you this bird for examination." On dissection I found the neck dislocated at the third joint from the head, and an appearance as if the sharp point of the hind claw had penetrated the brain at the occiput. Burdett informed me that such was the amazing rapidity with which the Peregrine skimmed over the surface of the water, that the Coot had no chance of escaping either by diving or by flight. Dr. Troughton of Coventry, in a note dated October 12th, 1860, says, "The Peregrine has returned to Coombe, committing devastation among the Coots and Pigeons." Now I regard the foregoing information with much 
interest, since it affords us an insight into the natural habits and economy of this destructive though noble bird; at the same time it must be admitted that this trait in its character, that of killing in mere wantonness or sport, is not commendable. Independently of Ducks, Coots, and Moor-hens, many other birds fall to the powerful stroke of the Peregrine's hind claw, such as Grouse, Partridges, Plovers, Pigeons, \&c. When used in falconry, it is flown at Herons, Crows, and other birds of equal magnitude; but as these are usually victims selected by the falconer, any details respecting its prowess in these cases would be somewhat out of place in a memoir on its natural history : but I may mention that there is no bird which is more easily tamed or rendered subservient to the desires of man, nor one that becomes more docile; for not only will it, at his will, pursue the quarry until it becomes a mere speck in the heavens, but from that altitude will respond to his lure and immediately descend, to be fed, and blinded by its stiff and uncomfortable hood; the cravings of its appetite appeased, it sits content on its accustomed block of wood, or rides with equal patience on the hand of the falconer or its "faire ladye."

The whole structure of the Peregrine is admirably adapted for aerrial progression, its powerful pectoral muscles, unparalleled among birds of its size, together with its long and pointed wings, enabling it ordinarily to pass through the air with a rapidity estimated by some writers at the rate of 150 miles an hour; but this rate of progression is as nothing compared with the impetuosity of its stoop when descending upon its quarry. Wonderful indeed is the rapidity with which this winged thunderbolt descends from aloft on any bird which may unwittingly pass beneath the rock or mountain escarpment upon which it has been reposing. Such a stoop as this I once witnessed in the Highlands. A flight of Ducks, which I had driven across the moor, caught the piercing eye of a Peregrine seated on a high rock about a mile distant. Down he came with meteor-like swiftness, when the Ducks, as if aware that it was their only chance of safety, doubled at once in the direction of the water they had left, both Ducks and Peregrine passing immediately over my head with the quickness of lightning and a rushing sound not easily to be described. Such a momentary scene as this can only be understood by those who have witnessed it; Mr. Wolf has endeavoured to convey some idea of it in the accompanying illustration. It will be seen that a Mallard has been struck dead, its back being ripped open by a stroke of the Peregrine's hind claw-a mode of striking in the air which I believe it always adopts. If perchance its aim should not be certain and effective, the Falcon usually mounts gracefully, sulkily seats itself on some neighbouring rock or tree, and patiently awaits another opportunity for repeating the same manœuvre. During my travels over the plains of Australia, Falcons frequently followed me for days together, on the chance of my raising a quail or other bird; and many fine stoops have I there witnessed.

Before leaving this part of the bird's economy, I may mention a remarkable stoop witnessed by my friend John Fowler, Esq., while shooting in Scotland. A small pack of Grouse being flushed, they descended to cross one of the deep gorges between the hills of the upper Findhorn, when a Peregrine, which had been quietly seated on a neighbouring high rock far above the birds, immediately gave chase, and almost with the quickness of thought was down upon his bird, and bore it away in his talons in face of the spectators above him. The consternation this sudden attack produced, not only in the pack of birds alluded to, but among all the Grouse on the hill-side, was such, that Mr. Fowler had excellent shooting for the next hour, whereas before the Grouse laid so badly that he could get no sport.

Few birds differ more in the size of the sexes than the Peregrine, and I have been very careful in ascertaining the relative weight of each whenever an opportunity offered; in this respect I have been most kindly aided by Mr. Benjamin Leadbeater, of Brewer Street, London, who has always submitted to my inspection any freshly killed specimens that have been sent to him; and I should be wanting in courtesy were I not to state that not only in this but in many other instances has Mr. Leadbeater been most obliging to me. The average weight of several females was 2 lbs. $5 \frac{1}{2}$ ozs.; and the total length 19 inches, of the wing $14 \frac{1}{2}$, of the tail $7 \frac{3}{4}$, of the tarsi $2 \frac{3}{8}$, and of the middle toe and nail $2 \frac{7}{8}$. There is no difference in the colour and markings of the male, of sufficient importance to be noticed. The average weight is $1 \mathrm{lb}$. 7 ozs., and the total length 16 inches.

The Peregrine breeds in April and May. The nest is usually placed upon the shelf of a rock, or near the top of a lofty tree; it is composed of sticks, sea-weed, hair, and other materials. The eggs are two or three in number, somewhat round in form, and of a deep russet-red, blotched and lined with a deeper hue.

The accompanying illustration represents an adult female about three-fourths of the natural size. It will be seen that the back is of a nearly uniform deep-blue grey, while the feathers of the abdomen and flanks are buffy white, barred with blue-grey. The young of the year is very differently marked,-all the upper surface being slaty brown, with a rufous border to each feather; the tail dark grey, crossed by five rows of sandy-buff spots assuming on the inner webs the form of bars; the breast and abdomen buffy white, with a broad longitudinal stripe of dark brown down the centre of every feather; the axillaries, too, which are regularly barred in the adult, are marked on each web with large spots of buffy white. This plumage is carried to the first monlt, when it is exchanged for that of the adult. 


\section{$2 \mathrm{BHL}$ Biodiversity Heritage Library}

Gould, John. 1873. "Peregrine Falcon, Falco peregrinus [PI. 17]." The birds of Great Britain 1, -. https://doi.org/10.5962/p.323797.

View This Item Online: https://www.biodiversitylibrary.org/item/221495

DOI: https://doi.org/10.5962/p.323797

Permalink: https://www.biodiversitylibrary.org/partpdf/323797

\section{Holding Institution}

Smithsonian Libraries

\section{Sponsored by}

Biodiversity Heritage Library

\section{Copyright \& Reuse}

Copyright Status: Public domain. The BHL considers that this work is no longer under copyright protection.

This document was created from content at the Biodiversity Heritage Library, the world's largest open access digital library for biodiversity literature and archives. Visit BHL at https://www.biodiversitylibrary.org. 